\title{
Description of a new ascaridoid parasite of Bothrops jararaca Wied (Reptilia, Ophidia) in Brazil
}

\author{
Liege R. Siqueira ${ }^{1}$, Márcia H. M. Panizzutti ${ }^{1,2}$, Luís C. Muniz-Pereira ${ }^{1}$ \& Roberto M. Pinto ${ }^{1,3,4}$ \\ 1 Laboratório de Helmintos Parasitos de Vertebrados, Departamento de Helmintologia, Instituto Oswaldo Cruz. Avenida \\ Brasil 4365, 21040-900 Rio de Janeiro, Rio de Janeiro, Brasil. \\ 2 Instituto de Biologia do Exército. Rua Francisco Manuel 102, 20911-270 Rio de Janeiro, Rio de Janeiro, Brasil. \\ ${ }^{3}$ Corresponding author. E-mail: rmpinto@ioc.fiocruz.br \\ ${ }^{4}$ CNPq Fellowship.
}

\begin{abstract}
A new species of Ophidascaris Baylis, 1920 is described on the basis of specimens recovered from the pit viper Bothrops jararaca Wied, 1824 in Brazil. The new species referred here was compared to other of the genus that are the closest. The differentiation was based on reliable morphological characters, mainly on what refers to the spicular length, number and distribution of caudal papillae, location of the vulvar opening, eggs size and aspect of the labial indentations. Moreover, female specimens are the only to possess a most prominent and characteristic post-anal tubercle-like structure and when analyzed together with the males, that show a great number of pre-cloacal papillae, the presence of an unpaired papilla and also of a less conspicuous post-cloacal tubercle-like structure, permit the prompt identification of the new species.
\end{abstract}

KEY WORDS. Nematoda, Ophidascaris, pit-viper, snakes.

RESUMO. Descrição de um novo ascarídeo parasito de Bothrops jararaca Wied (Reptilia, Ophidia) no Brasil. Uma nova espécie de Ophidascaris Baylis, 1920 é descrita, com base em exemplares parasitos de jararaca, Bothrops jararaca Wied, 1824 no Brasil. A nova espécie agora descrita foi comparada a outras do gênero que lhe são as mais próximas. A diferenciação foi baseada em caracteres morfológicos consistentes, principalmente nos que dizem respeito ao tamanho dos espículos, número e distribuição de papilas caudais, localização da abertura vulvar, tamanho dos ovos e aspecto das indentações labiais. Além disso, os exemplares fêmeas são os únicos no gênero a apresentarem uma estrutura em forma de tubérculo pós-anal bastante característica e proeminente, quando analisados junto aos exemplares machos, nos quais existe um grande número de papilas pré-cloacais, presença de papila caudal ímpar e, também, da estrutura pós-cloacal em forma de tubérculo, embora menos evidente que nas fêmeas, permitem a pronta identificação da espécie nova.

PALAVRAS CHAVE. Jararaca, Nematoda, Ophidascaris, serpentes.

Ascaridoid nematodes of different genera are very common in snakes worldwide and almost over 20 species have been allocated in the genus Ophidascaris Baylis, 1920; eight out of them have been reported in Brazilian hosts (VICENTE et al. 1993, PANIzZutTi et al. 2003).

An accurate examination of the nematodes parasitizing snakes is necessary to properly determine their exact inclusion, considering that individuals of different genera are very close to each other as occurs with the nematodes of the genera Ophidascaris and Hexametra Travassos, 1920, in which the generic status is based almost exclusively on the number of uterine branches that are of difficult observation, thus requiring a careful analysis to avoid that important morphological characters are overlooked.
The present paper deals with the description of Ophidascaris tuberculatum sp. nov. parasitizing specimens of Bothrops jararaca Wied, 1824 captured in the State of Rio de Janeiro, Brazil.

\section{MATERIAL AND METHODS}

Five specimens of $B$. jararaca, captured in wild environments, were maintained under captivity in the serpentarium of the Instituto de Biologia do Exército (IBEx), Rio de Janeiro, Rio de Janeiro, Brazil.

Wild snakes are kept in quarantine for adaptation and to avoid contamination of the other individuals of the colony already well adjusted to laboratory conditions. The animals that die during the adaptation process are investigated for endoparasites.

Revista Brasileira de Zoologia 22 (3): 587-590, setembro 2005 

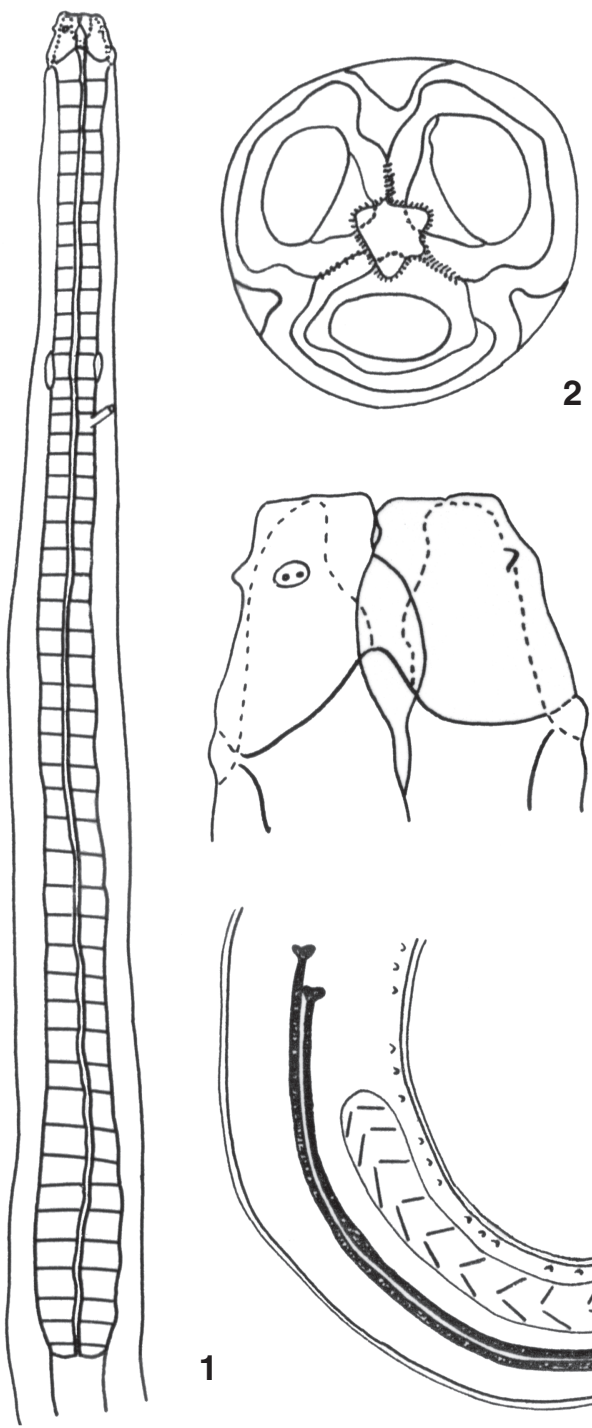

2
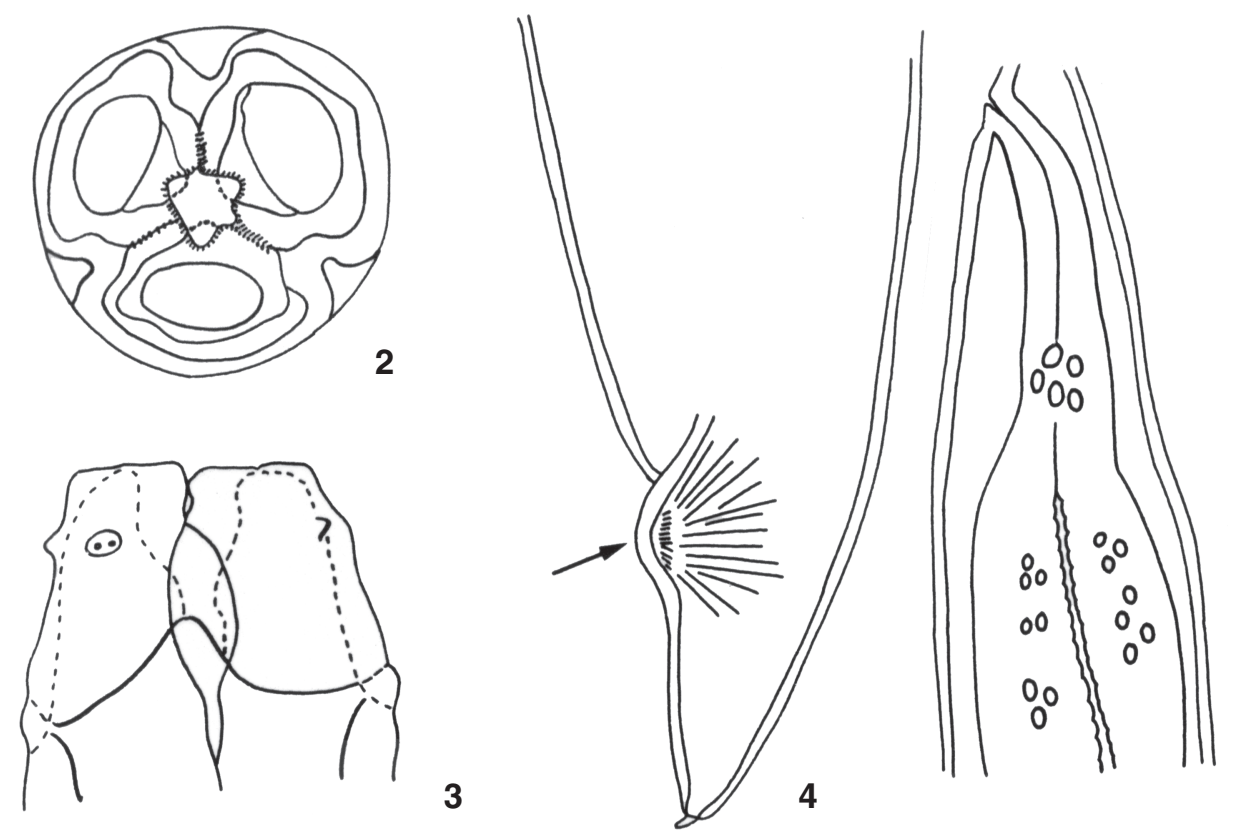

5

1

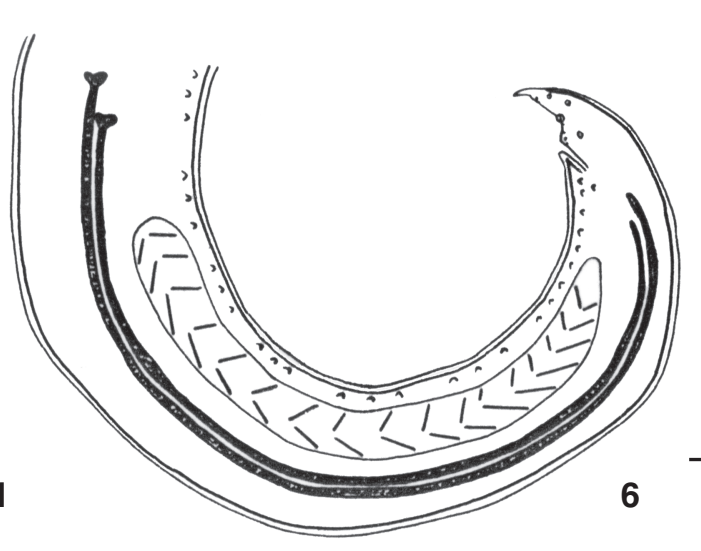

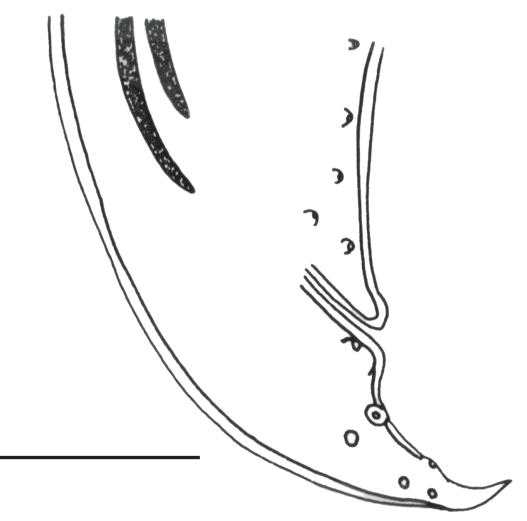

7

Figures 1-7. Ophidascaris tuberculatum sp. nov.: (1) anterior portion of the allotype, ventral view. Bar = $1.5 \mathrm{~mm}$; (2) "en face" view of the mouth of the allotype. Bar $=0.1 \mathrm{~mm}$; (3) anterior extremity of the allotype, ventral view. Bar $=0.2 \mathrm{~mm}$; (4) posterior portion of the allotype, showing the characteristic post-anal tubercle-like protuberance (arrow), lateral view. Bar $=0.5 \mathrm{~mm}$; (5) vulvar opening, ovijector and uterine bifurcation in the allotype, lateral view. Bar $=0.7 \mathrm{~mm}$; (6) posterior portion of the holotype, lateral view. Bar $=0.7 \mathrm{~mm} ;(7)$ posterior extremity of the allotype, lateral view. Bar $=0.5 \mathrm{~mm}$. Bar common to figures 1-7.

Necropsies were performed immediately after deaths, between September to December 2001, in accordance with the methodology of GOMEs \& PUERTo (1993). Organs were examined individually in Petri dishes with a $0.85 \% \mathrm{NaCl}$ solution.

Briefly, the recovered nematodes were fixed in hot A.F.A (glacial acetic acid 2\%; formaldehyde 3\%; $70^{\circ}$ ethanol 93\%), dehydrated in an a ethanol series $\left(70^{\circ}-100^{\circ} \mathrm{GL}\right)$ cleared acetic acid and phenol, unstained. En face mounts were obtained according to the method of ANDERSON (1958).
Specimens were kept either as wet material in A.F.A or preserved as whole mounts in beechwood creosote and Canada balsam (3:1). Samples were deposited in the Helminthological Collection of the Oswaldo Cruz Institute (CHIOC). Measurements are in millimeters $(\mathrm{mm})$ unless otherwise indicated and means are in parentheses. Drawings were obtained with a camera lucida connected to a Olympus microscope and photomicrographs in a Zeiss microscope in a Differential Interference Contrast (DIC) system. 

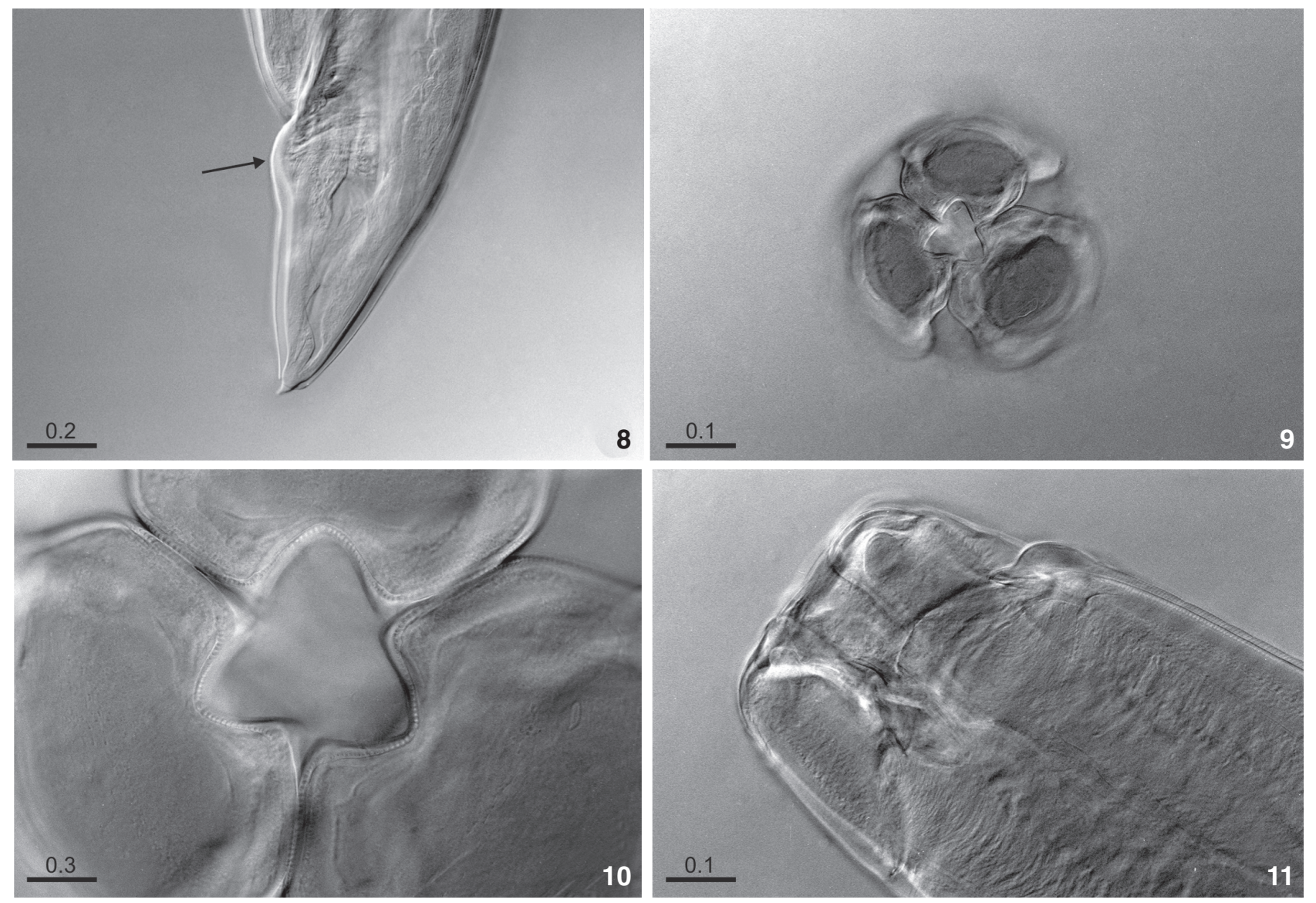

Figures 8-11. Ophidascaris tuberculatum sp. nov.: (8) posterior extremity of the allotype, with the characteristic post-anal tubercle-like protuberance (arrow), lateral view; (9) "en face" view of the mouth and lips of the allotype; (10) "en face" view of the mouth of the allotype, showing the labial indentations or dentigerous ridges; (11) anterior extremity of the holotype, ventral view. Measurements in millimeters.

\section{RESULTS}

\section{Ophidascaris tuberculatum sp. nov.}

Figs 1-11

Description based on six adult specimens, three males and three females.

Males 80-90 (85) long, 0.52-0.75 (0.73) wide; females 80150 (100.7) long, 0.93-1.02 (0.97) wide.

Mouth with three lips, each 0.17-0.20 (0.18) long, 0.100.23 (0.17) wide in males, 0.20-0.24 (0.21), 0.20-025 (0.22), respectively, in females. Dorsal lip with single and double lateroventral papillae. Labial indentations or dentigerous ridges well developed; interlabia present, not reaching the half portion of the lips. Esophagus 4.71-4.59 (4.64) long and 0.23-0.31 (0.26) wide in males, 5.90-6.10 (5.96), 0.35-0.39 (0.36), respectively, in females. Nerve ring and excretory pore 0.80-1.05 (0.85), 1.01.05 (0.98), respectively, from the anterior end in both sexes.

Males: spicules 2.45-2.90 (2.71) long. Tail pointed, with a conspicuous terminal mucron. Seventy-four caudal papillae: 30 pairs and 1 unpaired papilla are pre-cloacal, 1 pair is adcloacal, 5 pairs and 1 unpaired papilla are post-cloacal. This unpaired papilla is close to the tail end. Cloacal aperture 0.20$0.40(0.30)$ from posterior extremity.

Females didelphic, opisthodelphic. Eggs 0.075-0.080 (0.078) long, 0.061-0.080 (0.072) wide. Vulvar aperture not prominent, in the anterior middle third of the body; ovejector 1.07-1.20 (1.15) long. Conspicuous post-anal, muscular tubercle-like protuberance, with a rugose surface. Anal opening 0.20-0.50 (0.35) from posterior extremity.

Type host: Bothrops jararaca Wied, 1824 (Ophidia, Viperidae); common names: pit viper, "jararaca".

Site of infection: stomach.

Prevalence: $20 \%$.

Intensity of infection: 8 .

Type locality: Serra das Araras, Petrópolis, State of Rio de Janeiro, RJ, Brazil (22030'39"S; 4311'4”W), 857 m high.

Revista Brasileira de Zoologia 22 (3): 587-590, setembro 2005 
Studied specimens: Holotype CHIOC no. 36232 a, allotype CHIOC no. 36232 b (whole mounts), paratypes CHIOC no. 36232 c, d (whole mount), 35315 (wet material).

Etymology: the specific name is after the neuter Latin word tuberculatum meaning "having tubercles".

\section{DISCUSSION}

In the genus Ophidacaris Baylis, 1920, only three species can be compared to Ophidascaris tuberculatum:

Ophidascaris obconica (Baird, 1860) Baylis, 1921 redescribed by FreITAS (1968), based on specimens recovered from Helicops angulatus (Linnaeus, 1758) in Brazil, is similar to $O$. tuberculatum in the length of the spicules; nevertheless, it can be distinguished from the new species by presenting the vulvar aperture located in the posterior middle third of the body, whereas in the specimens studied here, the vulvar opening is at the anterior middle third region.

Ophidascaris ochoterenai proposed by CABALLERO (1939) on the basis of specimens recovered from Drymarchon corais melanurus (Boie, 1827) in Mexico, can be also associated to the specimens presently described by the spicular dimensions, number of post-cloacal papillae but differing by the location of the vulvar aperture, that similarly to the observed in $O$. obconica, opens in the anterior middle third of the body.

Ophidascaris sprenti described by Araujo (1969) based on nematode parasites of the rattlesnake Crotalus durissus terrificus (Linnaeus, 1758) in Brazil, can be considered closer to $O$. tuberculatum on what refers to some of the characters shared with O. ochoterenai and also by the size of eggs, the difference in the length of tail observed in males and females; nevertheless, males of $O$. sprenti possess a single pre-cloacal papilla-like protuberance lacking terminal enervation whereas males of O. tuberculatum, present a true, unpaired and enervate pre-cloacal papilla; also, in males as well as in females of the new species, the labial indentations or dentigerous ridges are prominent and large.

Most of all, O. tuberculatum differs from the other above referred species by the overall number and distribution of caudal papillae, pointed tail with a conspicuous terminal mucron observed in the males and by the very outstanding post-anal muscular tubercle-like protuberance with rugose surface presented by the females.

\section{REFERENCES}

Anderson, R.C. 1958. Méthode pour l'examen des nématodes em vue apicale. Annales de Parasitologie Humaine et Comparée, Paris, 33: 171-172.

Araújo, P. 1969. Nouvelle espèce d' Ophidascaris Baylis, 1921 parasite du serpent crotale (Crotalus durissus terrificus). Annales de Parasitologie Humaine et Comparée, Paris, 44: 441-450.

Caballero, C.E. 1939. Nemátodos de los reptiles de Mexico. III. Anales del Instituto de Biologia, México, 10: 73-82.

FreitAS, J.F.T. 1968. Revisão do gênero Ophidascaris Baylis, 1921 (Nematoda, Ascaridoidea). Memórias do Instituto Oswaldo Cruz, Rio de Janeiro, 66: 2-129.

Gomes, N. \& G. Puorto. 1993. Atlas anatômico de Bothrops jararaca (Wied, 1824) (Serpentes, Viperidae). Memórias do Instituto Butantan, São Paulo, 55: 69-100.

Panizzutti, M.H.M; L.C. Santos; J.J. Vicente; L.C.Muniz-Pereira \& R.M. PINTo. 2003. Ophidascaris durissus sp. nov. (Nematoda, Ascarididae) paraziting Crotalus durissus Linnaeus (Ophidia, Viperidae) in Brazil. Revista Brasileira de Zoologia, Curitiba, 20: 9-11.

Vicente, J.J; H.O. Rodrigues; D.C. Gomes \& R.M. Pinto. 1993. Nematóides do Brasil. Parte III: nematóides de répteis. Revista Brasileira de Zoologia, Curitiba, 10: 19-168.

Received in 19.X.2004; accepted in 22.VII.2005. 